\title{
INTERTEMPORAL DISCOORDINATION IN THE 100\% RESERVE BANKING SYSTEM
}

\author{
ROMAIN BAERISWYL*
}

Fecha de recepción: 16 de diciembre de 2014.

Fecha de aceptación: 2 de octubre de 2015.

Resumen: El plan «dinero 100\%» defendido por Fisher (1936) tiene connotaciones misianas en el sentido en que tiene como objetivo mitigar la descoordinación intertemporal reduciendo (i) la diferencia entre la inversión y el ahorro voluntario y (ii) la manipulación de los tipos de interés a través de inyecciones de dinero. Las recientes propuestas para adoptar un sistema de coficiente de reservas bancarias del 100\%, tales como el Chicago Plan Revisited de Benes y Kumhof (2013) o el Limited Purpose Banking de Kotlikoff (2010), toman, sin embargo, una actitud esencialmente diferente hacia el papel del banco central en el mercado de crédito, e ignora que la descoordinación intertemporal surge independientemente de si la expansión crediticia se financia mediante la creación de dinero desde dentro (inside money) o fuera (outside money). Estos planes permiten al banco central inyectar dinero desde fuera en el mercado de crédito y reducir los tipos de interés de manera efectiva en valores negativos con el fin de superar el límite que establece la trampa de la liquidez a la expansión del crédito en el sistema de reserva fraccionaria. Aunque tal intento puede tener éxito a la hora de estimular la economía en el corto plazo, acentúa la descoordinación intertemporal y debilita la estabilidad económica a largo plazo.

* Swiss National Bank. Email: Romain.Baeriswyl@snb.ch. The views expressed in this paper are those of the author and do not necessarily reflect those of the Swiss National Bank. The author thanks Katrin Assenmacher, Alexander Barkawi, Joerg Baumberger, Peter Bernholz, Dirk Faltin, Michael Jaquet, Enzo Rossi, Jack Tatom, an anonymous referee, and participants at the 2014 annual conference of the Association of Private Enterprise Education in Las Vegas, at the conference of the Council on Economic Policies on «Monetary Policy and Sustainability» at the Bellagio Center of the Rockefeller Foundation, at the conference of the Central Bank of the Republic of Azerbaijan on «Macroeconomic policies and financial stability issues in emerging markets» in Baku, at the conference of the University of Leipzig on «Exchange Rates, Monetary Policy and Financial Stability», and at the conference of the University of Witten on «Money, crisis and banking — an Austrian economic perspective» for their comments and useful suggestions. 
Palabras clave: Sistemas monetarios, banca de reserva del 100\%, Plan Chicago, teoría austriaca del ciclo económico.

Clasificación JEL: E30, E42, E58, B53.

Abstract: The 100\%-Money plan advocated by Fisher (1936) has a Misesian flavor as it aims at mitigating intertemporal discoordination by reducing (i) the discrepancy between investment and voluntary savings, and (ii) the manipulation of interest rates by monetary injections. Recent proposals to adopt the $100 \%$ reserve banking system, such as the Chicago Plan Revisited by Benes and Kumhof (2013) or the Limited Purpose Banking by Kotlikoff (2010), take, however, a fundamentally different attitude towards the role of the central bank in the credit market and ignore that intertemporal discoordination arises independently from whether the credit expansion is financed by the creation of outside or inside money. These plans allow the central bank to inject outside money into the credit market and to effectively lower interest rates in negative territory in order to overcome the limit that the liquidity trap sets to credit expansion in the fractional reserve system. Although such an attempt may succeed in stimulating the economy in the short run, it exacerbates intertemporal discoordination and weakens economic stability in the long run.

Key words: monetary systems, 100\% reserve banking, Chicago Plan, Austrian Business Cycle Theory.

JEL Classification: E30, E42, E58, B53.

\section{INTRODUCTION}

The recent economic crisis brought to light major weaknesses in our present financial system. The evident vulnerability of the economy to financial disruptions has focused the attention of policy makers and academics on the serious deficiencies of financial arrangements. Whereas nearly all observers would agree that something needs to be changed, there is, however, no consensus on what to change.

The various proposals to reform the financial system can be organized along two lines. The first line of reform, which is em- 
braced by most stakeholders in the system, would preserve the current monetary and financial framework, but strengthen the liquidity and capital requirements of institutions to improve their resilience to shocks. ${ }^{1}$ While the proponents of this view do not question the basis of the monetary system, they suggest reorganizing the way it works to make the outcome more acceptable.

The second line of reform, however, takes the radical view that the instability of the current system is embedded in its very nature and that modifying it at the margin will not bring about the desired stability. Its advocates therefore suggest that the monetary system and the process by which money is created be fundamentally changed.

This paper takes a closer look at the proposals recently made by Benes and Kumhof (2013) and Kotlikoff (2010) to abandon the fractional reserve banking system and adopt a system of $100 \%$ reserve against all check-account deposits. The idea of $100 \%$ reserve banking is not new. The proposal is drawn directly from the Chicago Plan or $100 \%$-Money plan advocated by Simons (1936) and Fisher (1936). The legitimacy of the fractional reserve banking system had also been the subject of the intensive debate between the Banking School and the Currency School in Great Britain in the nineteenth century.

The process by which money is injected into the economy has far-reaching implications. On the one hand, as emphasized by Cantillon (1755), an increase in the quantity of money is never neutral because economic sectors are affected unevenly by monetary injections. On the other hand, Mises (1912) shows that an injection of money into the credit market yields intertemporal discoordination as it creates a discrepancy between investment and voluntary savings, which gives rise to boom-bust cycles. This paper analyses the economic outcome of various monetary systems with regard to their influence on the Cantillon and Mises effects.

In light of this analysis, it turns out that the aim of the proposal by Benes and Kumhof (2013) is opposite to the purpose put forward in Fisher (1936). The 100\%-Money plan has a Misesian flavor as it seeks to mitigate intertemporal discoordination. Fisher (1936)

1 See for instance Admati and Hellwig (2013). 
promotes his plan by emphasizing that it would help to reduce the discrepancy between investment and voluntary savings, which occurs in the fractional reserve banking system, when commercial banks grant credit by creating money. He also stresses that, in his plan, interest rates would be freely determined by the demand for and supply of loanable funds, rather than continuously manipulated by monetary injections. By contrast, the Chicago Plan Revisited by Benes and Kumhof (2013) takes the opposite view, that the creation of money is equivalent to the creation of savings and, therefore, denies the possibility of intertemporal discoordination. For them, the advantage of their proposal consists in the central bank being better able to lower interest rates in negative territory, in order to overcome the limit that a liquidity trap sets to credit expansion in the fractional reserve system. Although such a plan may succeed in stimulating the economy in the short run, as credit expands further, it exacerbates intertemporal discoordination and weakens economic stability in the long run. Their proposal aims at dealing with the symptom of business cycles (i.e. financial instability), rather than the cause (i.e intertemporal discoordination). Limited Purpose Banking proposed by Kotlikoff (2010) suffers from the same weakness. Whereas it helps to mitigate intertemporal discoordination by converting commercial banks into pure financial intermediaries, the proposal provides for the injection of outside money by the central bank into the credit market, which exacerbates intertemporal discoordination.

The choice of monetary system must support the pursuit of the policy objective. The analysis shows that the pursuit of price stability in the fractional reserve system brings about unintended consequences, because the increase in money necessary to stabilize the price level is injected into the credit market, which exacerbates intertemporal discoordination. Two solutions to this dilemma are discussed: injecting money by means of government spending or lump-sum transfers to citizens and tolerating sound deflation.

The economic intuition behind the Cantillon and the Mises effects is explained in section 2. Section 3 presents the four basic monetary systems, which are then assessed against the Cantillon and Mises effects. Section 4 discusses and compares various proposals to adopt a $100 \%$ reserve banking system. Section 5 concludes. 
II

\section{THE EFFECT OF MONEY AND BANK CREDIT EXPANSION}

The monetary system determines the process by which money is created and put into circulation in the economy. Assessing the merit of various monetary systems requires a clear representation of the effect that an expansion of money has on the economy. This section presents the effect of an expansion of money on relative prices, the Cantillon effect, and the effect of an expansion of bank credit on intertemporal coordination, the Mises effect.

\section{The Cantillon effect: intersectoral distortion of monetary injection}

The effect of an increase in the quantity of money on the general level of prices was already observed in the sixteenth century, following the discovery of gold in Latin America. Cantillon (1755), however, was the first economist to highlight the fact that an increase in the quantity of money primarily affects relative prices rather than all prices in the same proportion, because money enters the economy at a certain point. Since money is not injected evenly into all markets at the same time, an increase in money has the greatest effect on the demand for and the price of the goods on which it is first spent. As money spreads into the economy, step by step, other markets are also affected by the monetary expansion.

Recognizing that an increase in money influences the relative demand for and price of goods, Cantillon concluded that changes in the quantity of money induce entrepreneurs to adjust the structure of production and the allocation of resources. Economic sectors in which the new money is first spent are at an advantage compared to the rest of the economy: entrepreneurs operating in the market where money is initially injected can increase and spend their revenue before prices have risen on other markets. As a result, an increase in money affects the distribution of income. The Cantillon effect is of prime importance for assessing various monetary systems because the process by which money is injected 
determines the economic sectors which benefit and those which suffer from monetary expansions.

For example, if money is injected into the real estate market, economic sectors closely related to that market will benefit most. In the first round, the increase in money benefits buyers of housing and construction companies. A buyer can take advantage of the increase in his money holdings to bid higher on the housing market, to the detriment of other potential buyers. A construction company will also benefit from the monetary expansion as the demand for housing rises, and it can spend its additional revenue before prices have risen on other markets. In the second round, the spending of the construction company will determine which sectors benefit next from the expansion. Not all sectors, however, derive advantages from the increase in money. Economic sectors whose demand is barely stimulated by the monetary expansion suffer from the rise in the prices of other goods, while their own prices remain unaffected. Assuming, for instance, that the increase in money leaves the demand for and the price of bread unaffected, then the monetary expansion will make bakers poorer because their nominal revenue remains stable while other prices, such as those for property, rise.

By contrast, if money is injected through the payment of lumpsum transfers to citizens, the monetary injection is likely to be less concentrated in the housing market in the initial stages; rather, it will be more broadly distributed across economic sectors, depending on how citizens spend their income.

In a nutshell, changes in the quantity of money are never neutral because they affect relative prices, the structure of production, the allocation of resources, and the distribution of income. The monetary system determines the process of monetary injection and influences the production structure of the economy.

To highlight the non-neutrality of money, imagine two economies that are identical in all respects, except that the first has a quantity of money and a price level twice as high as the second. Money would be neutral if it were possible for the second economy to double its quantity of money and its price level in such a way that it remains identical to the first economy in all respects. The outcome of this experiment depends on the process by which 
money is injected into the economy. If money is injected evenly through an imaginary helicopter drop (i.e. by a lump-sum transfer to each citizen), the new money will affect economic sectors according to the spending propensity of all citizens. Although the increase in money may evenly spread across sectors, it may nevertheless favor borrowers and lenders differently, unless it is perfectly anticipated. By contrast, if the doubling of the quantity of money is not injected evenly but enters the economy in specific markets, as it does in reality, changes in the quantity of money affect the allocation of resources, such that the second economy would not remain identical to the first one.

Note that modern macroeconomics ignores the Cantillon effect by assuming that money is evenly distributed across the whole economic population. ${ }^{2}$ Because this assumption implies that money is neutral, real effects of an increase in money are captured by exogenous frictions in price setting or in information gathering, rather than by directly accounting for the fact that the monetary injection per se is the source of heterogeneity between agents. The consensus, then, is that the real effects that money exerts in the short run spread evenly to the aggregate over time, such that money only affects the overall price level in the long run, leaving the real economy unaffected. Although the current macroeconomic view on money neutrality represents a significant progress on the Mercantilist view, according to which an increase in money is the source of wealth, it is an undeniable regression compared to the microeconomic analysis of Cantillon. These models therefore appear inappropriate to capture an essential feature of monetary systems.

\section{The Mises effect: intertemporal discoordination of bank credit}

The Mises effect can be considered an application of Cantillon's insight to the specific case where money is injected into the econo-

2 In the model of Lucas (1972) for instance, the monetary shock is assumed to affect all islands evenly. In New-Keynesian models, all goods within the Dixit-Stiglitz composite good are evenly affected by the Euler equation. Moreover, these models rely on the concept of the representative agent. 
my through the credit market. Relying on the subjective theory of value by Menger (1871), as well as the capital and interest theories of Böhm-Bawerk (1889) and Wicksell (1898), Mises (1912) develops a comprehensive business cycle theory which identifies intertemporal discoordination as the cause of business fluctuations. ${ }^{3}$

\section{a) Origin of the discrepancy between investment and savings}

Credit transactions are intertemporal transactions. In a credit transaction, the borrower and the lender exchange goods over time. The credit market is the process which coordinates the demand for loanable funds from borrowers (or investors) with the supply of loanable funds offered by lenders (or savers). The interest rate is determined by the demand for and supply of loanable funds, and reflects the subjective time preference of agents and the superior productivity of more time consuming, capital intensive (roundabout) production processes. ${ }^{4}$ The interest rate freely formed in the market signals to investors and to savers the relative scarcity of loanable funds. If the supply of funds voluntarily offered by savers in the market increases, the resulting decline in interest rates increases the discount factor and thus allows investors to engage in more roundabout projects, which were not profitable at the previous higher level of interest rates. As emphasized in the capital theory of Böhm-Bawerk (1889), the roundaboutness of the production structure adjusts to interest rates.

Mises analyses the effect of the increase in the quantity of loanable funds by means of money creation on intertemporal coordination. Although an injection of money has the same effect (i.e. a de-

\footnotetext{
${ }^{3}$ Intertemporal discoordination is understood in this paper as the discrepancy between investment and voluntary savings that arises when money is injected into the credit market. Note, however, that Hayek (1928) adopts a stricter definition of intertemporal discoordination and states that any intertemporal price manipulation entails discoordination even if the credit market and interest rates remain unhampered.

4 See Bernholz (1993) for a discussion on the reasons for the existence of interest rates according to Böhm-Bawerk (1889), and Kirzner (1993) for an excellent exposition of the pure time-preference theory of interest.
} 
cline in interest rates) on the credit market as an increase in the loanable funds voluntarily offered by savers, Mises emphasizes that the creation of money is not equivalent to an increase in voluntary savings. Investment financed with the increase in money is not backed by voluntary savings. Unlike voluntary savings, the creation of money does not require any economic agent to reduce present spending. On the contrary, the monetary expansion allows both the borrower and the successive recipients of the newly created money to increase their spending in concert. ${ }^{5}$ In response to lower interest rates, investors are disposed to engage in more roundabout projects, although voluntary savings has not increased. Mises highlights that intertemporal discoordination threatens the sustainability of the roundabout structure of production and makes the boom resulting from monetary expansion unsustainable. ${ }^{6}$

More generally, intertemporal discoordination can occur in every credit transaction involving a maturity mismatch. Funding long-term investments with short-term voluntary savings can yield intertemporal discoordination, as it creates a discrepancy between the duration of investment and the duration that resources are placed at the disposal of the investor. ${ }^{7}$ The expansion of bank credit (through money creation) represents, however, an extreme case of maturity mismatching in respect of two dimensions. First, credit expansion helps to increase the extent of maturity mismatching because investment is funded by money which has no maturity. Second, and more importantly, credit expansion helps to increase the volume of maturity mismatching because the money lent is created. In the absence of money creation, each granting of credit requires an equivalent volume of voluntary savings for, at least, a short period. When credit is granted through monetary injection, the quantity of credit is determined by the quantity of

${ }^{5}$ For example, the injection of money through the granting of mortgages allows the borrower to increase his spending as he buys a house and the construction company (the recipient of the new money) to increase its spending as it pays its suppliers and workers. These, in turn, are likely to spend the largest part of their revenue.

6 See Huerta de Soto (2009) for a modern and comprehensive exposition of the Austrian business cycle theory.

7 See Bagus (2010). 
money created and not by the quantity of (possibly short-term) voluntary savings.

b) Resolution of the discrepancy between investment and savings

At the macroeconomic level, the identity between investment and savings must hold. Macroeconomic savings is the portion of income which is not consumed and which corresponds to investment. The unhampered process by which the identity between investment and savings is satisfied is the loanable fund market. The level of the interest rate is determined in the unhampered market, such that the demand for investment equals the supply of savings. Yet, if this identity is not satisfied on the loanable fund market at the unhampered level of the interest rate in the wake of an increase in the quantity of money, other macroeconomic processes are set in motion to make the identity between investment and savings hold. Provided that a monetary expansion yields a discrepancy between investment and voluntary savings in the credit market, investment will be brought back in line with savings through

— an increase in forced savings ${ }^{8}$ by means of price increases, i.e. inflation, ${ }^{9}$

- an increase in forced savings by means of default, or

- a reduction in investment through liquidation.

The nature of the adjustment process in question depends on the type of maturity mismatch and, as discussed below, on the monetary system in place. Intertemporal discoordination requires time to be revealed by the market process and to turn into crisis. This process can be illustrated for the cases where investment is funded by money or short-term savings.

8 The term 'forced savings' is used in the sense of Garrison (2004), rather than in that of Hayek (1935).

${ }^{9}$ Inflation is understood here as a rise in prices (consumer goods, financial assets, real estate) that is relatively higher than it would be in the absence of monetary expansion (ceteris paribus). This means neither that the inflation rate must be positive nor that the consumer price index must rise. 
Consider first the case where investment is funded by an increase in money. If money holders hoard the new money for the duration of investment, there is no discrepancy between the voluntary savings of money holders and investment. By contrast, under the realistic assumption that money holders do not hoard their money holdings for the duration of investment but spend it to finance their transactions, the discrepancy between investment and voluntary savings will translate into an increase in demand and prices. The monetary expansion yields an inflationary boom. The rise in prices reduces the purchasing power of money and thereby reduces the possible real spending of other money holders. The reduction in real spending due to higher prices is tantamount to an increase in forced savings, and helps to make the identity between savings and investment hold. ${ }^{10}$ Assuming that the rise in prices leads to an increase in interest rates (as a result of action taken by a central bank, because commercial banks raise interest rates to stop an outflow of reserves or gold, or because lenders want to be compensated for inflation ${ }^{11}$ ), then the increasing costs of borrowing will slow down the credit-granting process and may force investments in need of refinancing into liquidation, as projects which were profitable at lower interest rates turn unprofitable. The slowdown in the expansion of bank credit and the liquidation of investment may trigger an economic crisis and the inflationary boom will collapse.

Consider next the case where long-term investment is funded by short-term savings. As long as short-term savers roll over their lending for the duration of the investment, no discrepancy between voluntary savings and investment appears. But as soon as short-term savers refrain from rolling over their lending, the discrepancy between voluntary savings and investment will translate into a rise in interest rates, as distressed investors try to convince savers to renew their lending by offering higher interest rates. The increase in interest rates may trigger an economic crisis, as it slows down the credit-granting process and reduces the profitability of investment, which may be forced into liquidation.

10 See Mises (1949) p. 554-556.

11 See Mises (1912) p. 394-403. 
If short-term obligations cannot be met in full or on time (i.e. in the case of default), short-term savers are restrained in their ability to spend, which, as in the case of inflation, is tantamount to an increase in forced savings.

The choice of monetary system is important for the development of the Mises effect. The ability of financial institutions to accommodate a shortfall in lending by creating money (owing to the reluctance of short-term lenders to roll over their lending) determines the extent to which investment and savings are brought back into line through inflation, default, or investment liquidation. For example, monetary accommodation from a central bank enables commercial banks to meet their liabilities without having to dump assets, which reduces the extent of default and investment liquidation, but increases that of inflation.

\section{III \\ MONETARY SYSTEMS AND THE LIMIT TO MONETARY EXPANSION}

A monetary system defines the set of rules regulating the institutions which create money. In this section, the four basic monetary systems are described briefly. Then the economic effect of monetary systems is analyzed by emphasizing the limit that each system sets to monetary expansion.

\section{The four basic monetary systems}

Monetary systems are characterized by the way in which money is injected into the economy. Money is the common medium of exchange. There are various kinds of money in circulation. For the sake of analysis, we distinguish two kinds of money: outside money and inside money.

Outside money is money created outside the private banking system and consists of proper currency. Outside money can be redeemable in precious metal or is unredeemable if it is fiat currency. Monetary systems can be distinguished according to whether out- 
side money is flexibly managed or not. A system where outside money is not flexibly managed is called a free banking system, whereas a system with flexibly managed outside money is referred to as a central banking system, as outside money is typically managed by a central bank.

Inside money, by contrast, is money created inside the private banking system and consists of currency substitutes such as bank deposits or monetary aggregates. Inside money is redeemable in outside money as it is a promise issued by a commercial bank to pay outside money on demand. Inside money is part of the overall quantity of money only to the extent that agents treat it as equivalent to outside money. Agents accept inside money as a final means of payment in place of outside money only insofar as they have confidence in the solvency of the issuing bank. Monetary systems can be distinguished according to whether commercial banks are allowed to issue inside money or not. A system where commercial banks cannot create inside money is called a $100 \%$ reserve banking system, whereas a system where commercial banks can create inside money is called a fractional reserve banking system.

Combining the relative flexibility of outside and inside money, monetary systems can be organized into four classes (Huerta de Soto 2009, 654-714):

1. In a $100 \%$ reserve free banking system, outside money is not flexibly managed, whereas commercial banks do not create inside money.

2. In a fractional reserve free banking system, outside money is not flexibly managed, whereas commercial banks create inside money.

3. In a fractional reserve central banking system, outside money is flexibly managed by the central bank, whereas commercial banks create inside money.

4. In a $100 \%$ reserve central banking system, outside money is flexibly managed by the central bank, whereas commercial banks do not create inside money.

The extent to which each monetary system puts a limit on monetary expansion is now discussed along the lines of the Cantillon and Mises effects. 


\section{The $100 \%$ reserve free banking system}

There is no monetary expansion in the $100 \%$ reserve free banking system, as inside money is fully backed by outside money, which is not flexibly managed.12 This corresponds to a system of pure financial intermediation, where credit transactions consist of intertemporal exchanges of pre-existing money. The system entails no financial externalities because each agent bears the entire risk associated with his actions.

In the absence of monetary expansion, the effect due to the non-neutrality of money, as described by Cantillon, does not apply. By contrast, the Mises effect can arise because a fixed quantity of money does not preclude, in principle, the occurrence of intertemporal discoordination. Maturity mismatching occurs without monetary injections whenever long-term investments are financed with short-term borrowing. As highlighted by Bagus (2010), although the fixed quantity of money characterizing the $100 \%$ reserve free banking system does not prevent maturity mismatching, it places severe restrictions on the extent to which maturity mismatching can develop.

As discussed in section 2.2, maturity mismatching creates a discrepancy between investment and voluntary savings as soon as roll-over lending falls short of the expected amount. ${ }^{13}$ This discrepancy must be resolved either by a reduction in investment through liquidation or by an increase in forced savings through inflation or default. The $100 \%$ reserve free banking system, however, precludes the accommodation of roll-over tightening through monetary expansion. This implies that discrepancies between investment and savings must be resolved by a combination of liquidation of long-term investment and default on short-term lending, rather than inflation.

Because it is impossible to accommodate roll-over tightening through monetary expansion, maturity mismatching is a risky ven-

12 If it is a commodity such as gold, the supply of outside money can vary with its production and in response to changes in its price.

13 See Bagus and Howden (2010) for a detailed analysis of the effect of the structure of savings on the yield curve. 
ture, both for borrowers and lenders. Sudden breaks in the roll-over of short-term lending endanger the success of long-term investment. Financial intermediaries or investors that engage aggressively in maturity mismatching can be forced into liquidation and bankruptcy as soon as short-term lending tightens. In turn, lenders exposed to aggressive maturity mismatching ventures face default risk. As a result, borrowers and lenders are induced to behave with the greatest prudence and to continuously check the extent of maturity mismatching of their ventures because they cannot be rescued by monetary expansion. The absence of financial externalities helps to restrict the extent of maturity mismatching, as each agent assumes the full economic responsibility of his acts.

In short, although the $100 \%$ reserve free banking system does not prevent intertemporal discoordination per se, the absence of monetary accommodation restricts its development within narrow limits.

\section{The fractional reserve free banking system}

In the fractional reserve free banking system, monetary expansion occurs as commercial banks increase the quantity of inside money. Outside money, however, is not flexibly managed. ${ }^{14}$ The key feature of an expansion of the fractional reserve (free as well as central) banking system consists of inside money being injected into the credit market as commercial banks grant loans. As the phrase goes, money is lent into existence. ${ }^{15}$

The significance of an expansion of inside money for the Cantillon and Mises effects will now be outlined. Subsequently, various arguments on the automatic adjustment and intrinsic stability of the fractional reserve system will be discussed.

14 The fractional reserve free banking system broadly corresponds to the gold standard, as operated in the 19th century. Whereas commercial banks issued inside money in the form of bank deposits, outside money, gold, was not flexibly managed by a central bank. The supply of monetary gold was nevertheless driven by the real price of gold.

15 See McLeay et al. (2014) for a description of money creation in the fractional reserve banking system. 


\section{a) Intersectoral distortion and intertemporal discoordination}

An expansion of inside money exacerbates the Cantillon and Mises effects because the new money is injected into the credit market.

According to the Cantillon effect, an expansion of money is not neutral if it does not reach all economic sectors and agents evenly at the same time. Since money injected through the granting of credit is typically spent on specific sectors in the first place, an increase in inside money exerts a stimulating effect which is unevenly distributed across economic sectors. An increase in inside money primarily stimulates sectors for which demand is stimulated by credit (such as housing or the automobile industry). An expansion in the fractional reserve system is thus not neutral because it benefits the economic sectors associated with monetary injections more than others.

Moreover, the Cantillon effect rationalizes the incentive behind the expansion of inside money (i.e. behind the emergence of the fractional reserve free banking system) by showing that it primarily benefits those who are closely involved in it. Whereas in a system of pure financial intermediation each agent assumes the full economic responsibility of his acts, in the fractional reserve system, commercial banks enter into credit (intertemporal) transactions at the risk of depositors whose newly created money is immediately available to settle payments. This process entails the essence of financial externalities.

The fractional reserve system exacerbates the intertemporal discoordination described by Mises. As explained in the previous section, intertemporal discoordination can occur without monetary expansion whenever long-term investment is funded with shortterm savings. An increase in inside money, however, exacerbates intertemporal discoordination in two ways. First, it increases the extent of discoordination because bank deposits have no maturity: long-term investment is funded with the creation of new money, which can immediately circulate to finance further transactions. Second, it increases the volume of intertemporal discoordination because the creation of inside money is not restricted by the savings behavior of economic agents. Contrary to the $100 \%$ reserve free banking system where any credit transaction requires an equiva- 
lent amount of savings (for a short period, at least), the fractional reserve banking system does not require any voluntary savings because the money lent is created ex nihilo.

The expansion of inside money is governed by the credit policy of commercial banks and is limited by the confidence of the public in the issuing banks. Since the quantity of outside money is not flexibly managed, the ratio of outside to inside money falls as the system expands. When commercial banks wish to attract an inflow of outside money or stop an outflow of outside money in order to ensure the confidence of the public, they tighten their credit policy. Hikes in interest rates slow down demand, reduce the profitability of investment, and cause investment losses. Ironically, the tightening of credit policy, which aims at ensuring the confidence of the public in inside money, may trigger losses, fears of bank insolvency, and runs on outside money. The impossibility of accommodating commercial banks' tightening by increasing outside money implies that the discrepancy between investment and voluntary savings must be resolved by means of liquidation and default, rather than by inflation. The default on inside money is tantamount to an increase in forced savings (as depositors endure losses) and leads to a contraction of money and credit. Thus, the combination of flexible inside money with fixed outside money is prone to pronounced boom-bust cycles.

\section{b) On the automatic adjustment of the fractional reserve system}

At this stage, it is worth to mention two arguments that have been advanced in favor of the fractional reserve banking system. The first argument, known as the real bills doctrine, claims that the fractional reserve banking system automatically adjusts to fluctuations in business needs. The second argument, known as the monetary equilibrium theory, claims that the system automatically adjusts to fluctuations in money demand. These arguments assert that the expansion in the fractional reserve system is an automatic stabilizer of the economy. Proponents of these views overlook, however, the fact that both business needs and the demand for money are not exogenous, but depend on the credit pol- 
icies pursued by commercial banks. The fractional reserve system, thus, fails to automatically stabilize economic fluctuations.

The real bills doctrine - According to the real bills doctrine as put forward by Fullarton (1844), the expansion of the fractional reserve free banking system naturally adjusts to business needs since inside money is created when commercial banks grant credit. The relationship between the creation of money and the granting of credit is seen as a means of providing the optimal quantity of money. The quantity of inside money increases when money is needed to finance credit transactions. The creation of inside money can never exceed its demand because money automatically adjusts to the volume of transactions. When business needs increase, inside money adjusts to satisfy the rise in demand for credit. Money remains in circulation as long as businesses need it. When businesses need less credit, inside money automatically contracts as bank loans are repaid. Expansion and contraction of inside money are seen by the real bills doctrine as the consequence, never the cause, of fluctuations in business activity. The proponents of the real bills doctrine assert that the automatic adjustment of inside money to business needs is not inflationary because the money created by credit expansion flows back to banks when credit contracts.

As highlighted by Mises (1912), the fallacy of the real bills doctrine is based on the assumption that business needs are exogenous, i.e. independent of the credit policy pursued by commercial banks. ${ }^{16}$ Since the profitability of investment depends on the level of interest rates, the credit policy of commercial banks influences the demand for credit. The demand for credit expands as interest rates fall, and contracts as interest rates rise. When commercial banks pursue an expansionary credit policy, they induce an increase in the demand for credit by reducing interest rates. The fractional reserve free banking system cannot adjust to business needs because business needs themselves are dependent on the interest rate that commercial banks demand for granting credit. Fluctuations in the demand for credit may thus reflect the credit policy of commercial banks rather than exogenous changes in business

16 See Mises (1912), p. 339-347. 
needs. Thus, the fractional reserve free banking system does not naturally help to stabilize the economy but can rather exacerbate the emergence of intertemporal discoordination, as business fluctuations react to the credit policy of commercial banks.

The monetary equilibrium theory - The second argument supporting the fractional reserve banking system states that it automatically accommodates fluctuations in money velocity by adjusting the quantity of inside money. Selgin (1994) shows, within a fractional reserve model, that commercial banks optimally increase the supply of inside money and credit in response to a decline in money velocity, i.e. to an increase in money demand. The decline in money velocity reduces the outflow variability of outside money and, thereby, the need for banks to hold precautionary outside money. The reduction of the quantity of outside money held by banks for precautionary reason corresponds to an increase in the quantity of outside money held in excess to the precautionary threshold. The increase in excess outside money in response to a decline in money velocity allows commercial banks to expand credit and to increase the supply of inside money. So the system accommodates any increase in the demand for money with a corresponding increase in the supply of money. This mechanism is seen as maintaining monetary equilibrium and contributing to the stability of both the purchasing power of money and of business fluctuations.

As highlighted by Bagus and Howden (2010a) and Huerta de Soto (2009), the monetary equilibrium theory repeats basically the same error as the real bills doctrine by ignoring the fact that the demand for money is dependent on the credit policy pursued by commercial banks. The demand for money is typically negatively related to interest rates: it tends to increase when the opportunity costs of money holding (i.e. interest rates) fall. The fractional reserve banking system cannot reconcile an increase in the demand for money with an expansion in inside money because it is endogenously determined by its credit policy. Thus, fluctuations in money demand cannot serve as a limit to credit expansion.

Moreover, accommodating an increase in money demand with an expansion of credit also exacerbates the Mises effect. It is important to note that there is no necessary relationship between the 
demand for money and savings. The demand for money can change without a corresponding change in time preference or the consumption-savings relationship. An increase in money demand can indeed result from a reduction in both consumption and investment spending. While spending less on consumption constitutes an increase in savings and a decline in time preference, spending less on investment reflects an increase in time preference. If the fractional reserve system accommodates an increase in money demand, it may increase the supply of credit as time preference increases. Since it is not possible to identify the cause of fluctuations in money demand, systematically accommodating them with credit expansion can exacerbate intertemporal discoordination.

Since business needs and the demand for money are dependent on the credit policy pursued by commercial banks, they do not set a limit to the expansion of the fractional reserve free banking system. The expansion of the system is only limited by the confidence of the public in the issuing banks. Because it is impossible to accommodate the interest rate tightening that results from intertemporal discoordination by increasing outside money, this makes the system prone to pronounced boom-bust cycles. As argued by Huerta de Soto (2009), the instability inherent in the fractional reserve free banking system makes it inevitable that a central bank will be established as a lender of last resort, ready to grant banks the outside money they need during the recurrent stages of crisis. ${ }^{17}$

\section{The fractional reserve central banking system}

In the fractional reserve central banking system, commercial banks create inside money by granting credit, while the central bank manages the quantity of outside money in a flexible manner. ${ }^{18}$ We restrict our attention to the case where the central bank injects outside money, either through credit transactions with

17 In many countries, the role of central bank as lender of last resort has been taken by the already existing government or state bank.

18 This corresponds to the current monetary system. 
commercial banks (like repo operations) or through straight purchases of financial assets. ${ }^{19}$ In normal times, the central bank orchestrates the development of the fractional reserve system by controlling the relative scarcity or price of outside money on the credit market. An increase in outside money reduces interest rates and induces commercial banks to expand the supply of credit and inside money. A contraction of outside money and a hike in interest rates slow down the expansion.

The emergence of the central bank enhances the expansion of the fractional reserve system and thereby exacerbates both the Cantillon and Mises effects. The central bank exerts a double-edge effect on the expansion of the fractional reserve system. On the one hand, it attenuates the severity of boom-bust cycles because it can accommodate the credit tightening brought about by intertemporal discoordination, by increasing outside money. The discrepancy between investment and voluntary savings that arises along an expansion of the fractional reserve system must not necessarily be resolved by liquidation of investment and default on inside money, but can be resolved through an increase in outside money. Historically, the reason why many central banks were established as lenders of last resort was precisely to enable commercial banks to meet depositors' demand for outside money without having to dump assets. An expansion of the fractional reserve is thus not necessarily followed by a reverse contraction of inside money and credit (debt-deflation spiral), as in the fractional reserve free banking system. On the contrary, the expansion of inside money has a permanent inflationary effect.

On the other hand, the central bank exacerbates intertemporal discoordination because the flexible management of outside money enhances the expansion of the fractional reserve system. As discussed in the previous section, the expansion of the fractional reserve free banking system is limited by the confidence of the public in the banks issuing inside money. Since bank insolvency in the fractional reserve system is tantamount to a disruption of the

19 The case where the central bank injects outside money into the economy through government spending or lump-sum transfers to citizens is left to the discussion of the next system, i.e. the $100 \%$ reserve central banking system. 
payment system, the incentive for the central bank to bail out commercial banks in trouble is very high. The emergence of the central bank strengthens the confidence of the public in inside money, because it reduces the recurrence and severity of bank insolvency, and pushes the limit to the expansion of the system further. ${ }^{20}$ This, in turn, makes the need for the central bank to accommodate even greater, as the system expands: exacerbated intertemporal discoordination increases the threat and the severity of a potential debt-deflation spiral. Of course, the extent to which the central bank accommodates expansions depends on the policy objective that it follows.

The limit to the expansion of the fractional reserve central banking system can be addressed separately for inside money and outside money. Provided that the central bank is ready to grant commercial banks as much outside money as they need to bail them out, the confidence of the public in inside money will be total. The expansion of the fractional reserve central banking system is, nevertheless, limited by the occurrence of a liquidity trap, which is the situation where the supply of credit by commercial banks and/or the demand for credit by economic agents does not expand in response to an increase in outside money. If inside money does not expand any further, the central bank can exert a direct expansionary effect on the credit market through injections of outside money into financial markets, known as quantitative or credit easing. The only limit to quantitative easing is set by the confidence of the public in outside money. Since outside money is not redeemable, a loss of confidence in outside money would imply that the public ceases to use it as a common medium of exchange, which is tantamount to high inflation.

The occurrence of a liquidity trap induces the central bank to become more directly involved in the expansion of money and credit, as the transmission mechanism through the fractional reserve system becomes ineffective. This leads us to consider the final monetary system, the $100 \%$ reserve central banking system, where money is exclusively created by the central bank.

${ }^{20}$ Deposit insurance also contributes to increase the confidence of the public in inside money. 


\section{The $100 \%$ reserve central banking system}

In the $100 \%$ reserve central banking system, the entire quantity of money is issued by the central bank as outside money, while commercial banks are not allowed to issue inside money. This implies that bank deposits are fully backed by central bank money. There are various proposals for the process by which the central bank injects outside money into the economy. Outside money can be injected through lump-sum transfers to citizens and to the government or through the granting of credit to financial intermediaries. Because these two competing processes have different implications for the development of the Cantillon and Mises effects, they are discussed separately. ${ }^{21}$

a) Outside monetary injections through lump-sum transfers to citizens or to the government

The first process by which the central bank can inject outside money into the economy consists of providing citizens or the government with the amount of money that the central bank decides to create. In turn, citizens or the government use the new money to finance their spending. In other words, money is spent into existence. The expansion is only limited by the confidence of the public in outside money. The creation of money becomes independent of the granting of credit because outside money is not issued through the granting of credit. In this system, the credit market is made up of pure financial intermediaries without the privilege of creating inside money, which merely lend the pre-existing money they have borrowed. Thus, an increase in money is permanent because money is not automatically destroyed as credit is paid back. In a growing economy, the central bank is likely to increase the quantity of money continually, in line with the growth of production. The central bank could, nevertheless, withdraw money from circulation, either by issuing non-monetary papers (such as bonds, in which

${ }^{21}$ Proposals in favour of the $100 \%$ reserve central banking system may, however, allow a combination of both processes of monetary injections. 
case the withdrawal of money would affect credit market) or through a reverse monetary transfer from citizens or the government to the central bank. The government can raise the money to be returned to the central bank through taxation or by issuing debt.

The Cantillon effect induced by an injection of outside money through lump-sum transfers is determined by the specific changes that the increase in money exerts on citizens' spending and on the government budget. For example, if the new money is evenly distributed across the whole population through a lump-sum transfer to citizens, the Cantillon effect would be limited. But if the government takes advantage of the monetary expansion to reduce the rate of taxation, the benefit from the increase in money will be less evenly distributed. In this case, only those who pay taxes will initially benefit from the monetary expansion. ${ }^{22}$ However, the increase in money can also benefit specific sectors if the government intends to raise its spending in specific areas, such as public infrastructure. Depending on the political decision on how to allocate the new money, the injection of outside money through government spending can mitigate or exacerbate the Cantillon effect, compared to an expansion of the fractional reserve banking system, where money is first spent on markets stimulated by credit.

The injection of outside money through lump-sum transfers mitigates the Mises effect because money is not injected into the credit market. ${ }^{23}$ As highlighted in section 3.3, the key feature of the fractional reserve banking system is that an injection of inside money coincides with the granting of credit, which exacerbates intertemporal discoordination. Yet, when money is spent into existence by citizens or the government, an expansion of money exerts no direct effect on credit granting. Although this may reduce the demand for credit from the government, the credit market is nevertheless characterized by pure financial intermediation, where the quantity of credit is determined by the unhampered interest

${ }^{22}$ Lower taxation rates may stimulate growth, which would benefit a broader circle of people over time.

23 See Mises (1949) p. 553: «If the additional quantity of money enters the economic system in such a way as to reach the loan market only at a date at which it has already made commodity prices and wage rates rise, these immediate temporary effects upon the gross market rate of interest will be either slight or entirely absent.» 
rate, which reflects the superiority of roundabout production processes and the subjective time preference of investors and savers. This helps to improve intertemporal coordination and mitigates the discrepancy between investment and voluntary savings.

Moreover, when money is injected through lump-sum transfers, the $100 \%$ reserve central banking system reduces the incentive of the central bank to accommodate roll-over tightenings through monetary expansion because the payment system is not placed at risk in the case of insolvency of financial intermediaries. As discussed in section 3.2, maturity mismatching can occur even in the absence of monetary expansion. This can also occur when outside money is injected through lump-sum transfers rather than granting of credit (especially if the government spends the money on long term investment projects). But compared to the fractional reserve central banking system, the incentive of the central bank and of the government to accommodate roll-over tightening and to bail out banks is lower, because the payment system is not reliant on the insolvency of financial intermediaries. Since such insolvency does not trigger any disruption of the payment system, the central bank and the government have less incentive to bail them out. Maturity mismatching becomes a riskier venture in the $100 \%$ reserve system than in the fractional reserve system. This reduces financial externalities and induces borrowers and lenders to behave with more prudence and to better check the extent of maturity mismatching of their ventures.

\section{b) Outside monetary injections through the granting of credit}

The second process by which the central bank can inject outside money into the economy is to grant credit to financial intermediaries. Money is exclusively created by the central bank, but initially it enters the credit market, as in the fractional reserve system. The quantity of credit granted by financial intermediaries is determined by the money lent to them by either the central bank or savers. The central bank thus exerts a control not only over the quantity of money, but also over the quantity of credit and over interest rates. 
Compared to the fractional reserve central banking system, injecting outside money through the granting of credit to financial intermediaries pushes the limit of credit expansion further and potentially exacerbates intertemporal discoordination. When the fractional reserve central banking system is in a liquidity trap, the central bank can try to stimulate the credit market with quantitative or credit easing. The effectiveness of such measures depends however on the willingness of commercial banks to expand their balance sheets and on the ability of the central bank to lower interest rates in negative territory. Such a trap does not exist in the $100 \%$ reserve central banking system because the central bank directly controls the quantity of money in circulation and because it can easily enforce negative interest rates. Since credit granted by the central bank is only accessible to financial intermediaries for the specific purpose of funding investment projects, negative interest rates can be more effectively implemented than in the fractional reserve system. Moreover, enforcing negative interest rates requires the abolishment of cash, which is politically much easier to implement under the $100 \%$ reserve than under the fractional reserve banking system. Abolishing cash in the fractional reserve system is indeed controversial because people can only hold outside money (legal tender) in the form of cash in that system. In the $100 \%$ reserve central banking system, however, since the entire quantity of money consists of outside money, abolishing cash merely means a reduction in the various kinds of outside money available to people.

Economically, a negative interest rate corresponds to a subsidy that the central bank makes to entrepreneurs. This allows entrepreneurs to undertake projects with a negative net present value. Although the economic sense of subsidizing unprofitable investments must be questioned, such a policy allows credit to expand further. ${ }^{24}$ With negative interest rates, the only limit to outside monetary injections through the granting of credit is set by the confidence of the public in outside money.

${ }^{24}$ Note that the question of whether it makes economically sense to finance unprofitable investments does not arise only in the case where interest rate is negative, but generally whenever the interest rate is reduced below its unhampered level. 
The term 100\% reserve central banking system actually stands for two processes whereby outside money is injected whose macroeconomic effects are opposite to one another. While injecting outside money through lump-sum transfers to citizens or to the government reduces intertemporal discoordination as long as the central bank abstains from intervening in the credit market, injecting outside money through the granting of credit to financial intermediaries potentially exacerbates intertemporal discoordination, as interest rates can be more effectively lowered below zero.

IV

MONETARY SYSTEMS AND THE MONETARY POLICY OBJECTIVE

In this section, we discuss whether the proposals to abandon the fractional reserve central banking system in favor of the $100 \%$ reserve central banking system help to improve economic stability. We address the problem of the pursuit of price stability in the fractional reserve central banking system. Then, we contrast the 100\%-Money plan of Fisher (1936) with the Chicago Plan Revisited recently advocated by Benes and Kumhof (2013). Finally, the Limited Purpose Banking of Kotlikoff (2010) is discussed in respect to intertemporal discoordination.

\section{The problem of the pursuit of price stability in the fractional reserve system}

In a growing economy, the price level will tend to decline whenever the quantity of money is fixed. Deflationary pressures will arise along with technological progress. In order to stabilize the price level, the quantity of money must increase to offset deflationary pressures. Depending on the process by which money is injected into the economy, the increase in money necessary to stabilize the price level may have more or less pronounced Cantillon and Mises effects. In the fractional reserve central banking system, because money is injected as commercial banks grant credit, the pursuit of 
price stability yields an expansion in credit which induces entrepreneurs to engage in more roundabout production processes and exacerbates intertemporal discoordination. The pursuit of price level stability in the fractional reserve system thus brings about unintended consequences and is incompatible with economic stability. The difficulty of stabilizing the price level without exacerbating intertemporal discoordination is addressed in the $100 \%$-Money plan by Fisher (1936), on page 139:

... even when the price level is, for a time, successfully stabilized under the [fractional reserve] system, the very effort to accomplish this by manipulating the rates of interest, in the face of the handicaps of that system, necessarily requires some distortion of the rate of interest from normal, that is, from the rate which the mere supply and demand of loans would have produced.

Using the same line of argument, authors such as Phillips et al. (1937) and Rothbard (1963) identify the pursuit of price stability by the Federal Reserve Bank of the United States since the beginning of the 1920s, and the strong credit expansion that this objective required, as the major cause of the Great Depression. For instance, Phillips et al. (1937) claim that:

The end result of what was probably the greatest price-level stabilization experiment in history proved to be, simply, the greatest depression.

Two solutions to this dilemma have been proposed in the academic literature: to change the system or to change the objective. ${ }^{25}$ The first solution, endorsed among others by Mises (1912), Rothbard (1962) and more recently Huerta de Soto (2009), would be to tolerate sound deflation. It is important to emphasize the difference between sound deflation, which reflects the effect of technological progress on the price of goods, and a debt-deflation spiral, resulting from the contraction of money and credit following an

${ }^{25}$ Macroprudential instruments, such as capital requirements, may aim at solving this dilemma. However, it is difficult to see how such instruments would not affect both the creation of money and the granting of credit at the same time, leaving the dilemma unresolved. 
expansion in the fractional reserve system whenever it is not counteracted by an injection of outside money. Since our modern financial system is highly leveraged, mainstream economists typically associate deflation with a contraction of money and credit which brings on a depression. Deflation, however, must not always be associated with an economic depression. On the contrary, Friedman and Schwartz (1963), Atkeson and Kehoe (2004), and Bordo et al. (2004) document that several decades of the nineteenth century in the United States were characterized by the concurrence of deflation and strong real economic growth.

Tolerating sound deflation requires the absence of monetary manipulation, which is the main feature of the $100 \%$ reserve free banking system as advocated by Huerta de Soto (2009). Without monetary expansion, both the intersectoral distortion emphasized by Cantillon and the intertemporal discoordination put forward by Mises are mitigated. For instance, Angell (1935), another proponent of the $100 \%$ reserve banking, recommends not to compensate the reduction of prices owing to technological progress with an expansion of the money supply. His argument relies on both the Cantillon effect (page 23):

It seems more likely that the benefits of technological advance will be distributed with some approach to equality if prices fall than if money incomes must be raised ...

and the Mises effect (page 24):

[An increase in money] has the result that interest rates are kept lower than they otherwise would be, that some investment is being undertaken which cannot support itself over time or which is ill-advised in other ways, and that a subsequent painful and wasteful readjustment must take place.

The second solution to the dilemma is to separate the creation of money from the granting of credit, such that the pursuit of price stability disrupts intertemporal coordination less intensely. The objective of the 100\%-Money plan of Fisher (1936), as discussed below, is to control the price level without influencing the credit mar- 
ket. When the central bank renounces the management of interest rates and the credit market, and instead injects outside money through lump-sum transfers to citizens, intertemporal discoordination does not occur through the pursuit of price stability. The Chicago Plan Revisited by Benes and Kumhof (2013), however, does not follow this objective, but rather aims at enhancing the control by the central bank over the credit market.

\section{The $100 \%$-Money plan by Fisher (1936)}

Fisher (1936) asserts that his plan insulates the credit market from money creation, which mitigates the discrepancy between investment and voluntary savings that arises in the fractional reserve system. Fisher was not aware of the business cycle theory developed by Mises (1912), nor was the mitigation of intertemporal discoordination the main purpose of his proposal. ${ }^{26}$ His plan rather aimed at restoring complete government control over the quantity of money in circulation and its value. Nevertheless, he appears to support the fundamental Misesian belief that it is not desirable to replace the voluntary savings that is necessary to finance sustainably roundabout investments, with an injection of money. For instance, on page 111, Fisher (1936) states:

The growth of the country would be largely registered by the growth of savings and investments and these two (savings and investments) would keep more nearly synonymous than they are now; for the correspondence between them would not be so much interfered with as it is now - that is, interfered with in boom times by loans unwarranted by savings, and in depression times by savings hoarded instead of invested.

Fisher also highlights that, in his plan, interest rates remain unmanipulated by monetary expansions but reflect subjective time preference, as page 140 shows:

26 The plan of Fisher diverges from the proposal of Mises in that it promotes an active management of money by the central bank (i.e. 100\% reserve central banking), while Mises calls for unmanipulated money (i.e. 100\% reserve free banking). 
Interest rates would seek their level in a natural way according to the supply and demand of loans, and real rates would not be perverted by misbehavior of money.

In brief, the 100\%-Money plan advocated by Fisher (1936) aims at precluding the influence of monetary injections on the credit market. This mitigates intertemporal discoordination and improves economic stability.

\section{The Chicago Plan Revisited by Benes and Kumhof (2013)}

Although the proposal by Benes and Kumhof (2013) to adopt a $100 \%$ reserve central banking system is drawn from the 100\%-Money plan advocated by Fisher (1936), it takes, however, a fundamentally different attitude towards the role of the central bank in the credit market. Benes and Kumhof (2013) argue that significant control of the central bank over credit is highly desirable. In their proposal, referred to as the Chicago Plan Revisited, separation of money and credit functions at commercial banks allows the central bank to control more effectively the interest rate at which it lends outside money to financial intermediaries (or to credit departments of commercial banks). The aim of their system is not to favor the correspondence between investments and voluntary savings, as advocated by Fisher, but, on the contrary, to allow the central bank to steer the quantity of investment without any constraint stemming from savings or from the existence of a liquidity trap.

Benes and Kumhof (2013), as well as Huber (2011), ${ }^{27}$ hold the (mistaken) view that the creation of money is equivalent to the creation of savings, as they ignore the time dimension characterizing credit transactions and consumption-savings decisions. The quantity of credit and investment is thus determined completely independently of the quantity of voluntary savings, as asserted by Benes and Kumhof (2013) on page 12:

27 See Bagus (2014) for a critique of Huber. 
And it is the transfer of the deposit account balance from the investor in plant and machinery to the seller of plant and machinery that generates the corresponding savings, which is therefore a consequence of the creation of purchasing power and of physical investment activity. Because it implies that, at least to the extent that investment is bank-financed, the often heard prescription that in order to generate adequate levels of investment the economy first needs to generate sufficient savings is fundamentally mistaken. Because the credit system will generate the saving along with the investment.

In other words, they deny the existence of a discrepancy between investment and voluntary savings, which is essential for understanding the purpose of Fisher. Their statement is surprising because they spend a lot of effort to describe the process by which commercial banks - contrary to true financial intermediaries create the money they lend. One may wonder why this specific feature of commercial banks is worth mentioning if the created money is claimed to be equivalent to the savings collected by true financial intermediaries. In fact, it is important to emphasize that commercial banks create the money lent precisely because it is not equivalent to voluntary savings. Moreover, they emphasize that their system is more effective for lowering interest rates for investments below zero, which is tantamount to exacerbating intertemporal discoordination. For instance, on page 10, Benes and Kumhof (2013) states:

And liquidity traps are episodes during which the central bank cannot effectively stimulate the economy [...] because reductions in policy rates are impossible because of a zero interest rate floor. Neither of these «traps» can exist under the Chicago Plan [Revisited] [...] because the interest rate on treasury credit is not an opportunity cost of money for asset investors, but rather a borrowing rate for a credit facility that is only accessible to investment trusts for the specific purpose of funding physical investment projects, it can temporarily become negative without any practical problems. In other words, a zero lower bound does not apply to this rate.

For them, the 'problem' of the fractional reserve central banking system is not that investments are financed by new money per se, but that the new money is created as inside money and that the 
fear of insolvency of commercial banks puts an end to credit expansion. They favor the $100 \%$ reserve central banking system not because it prevents monetary expansions to distort the credit market, as Fisher does, but because credit is financed by the central bank with outside money, which is not redeemable. Intertemporal discoordination, however, occurs independently from whether the credit expansion is financed by outside or inside money.

To put it differently, the proposal of Benes and Kumhof (2013) aims at dealing with the symptom of business cycles (i.e. financial instability), rather than the cause (i.e. intertemporal discoordination). For the sake of illustration, imagine that the entire financial system would have merged with the central bank a year before the outbreak of the recent financial crisis. Of course, under such an hypothetical scenario, there would have been no financial crisis because the central bank cannot default on unredeemable outside money. Nevertheless, the misallocation of resources brought about by intertemporal discoordination would have taken place anyhow. Financial instability brings to light the underlying intertemporal discoordination and induces market participants to adjust their venture to a state of affairs compatible with subjective time preference. From this point of view, financial instability is not a calamity per se, but the market process which puts an end to the calamitous intertemporal discoordination and through which the economy is brought back onto a sustainable path. Enhancing central bank control of the credit market potentially exacerbates intertemporal discoordination as it enables the central bank to overcome the limit to expansion set by financial instability (i.e. by the liquidity trap).

In the short run, the proposal by Benes and Kumhof (2013) should make it easier for the central bank to boost the economy through a further round of credit expansion. In the long run, however, by ignoring Fisher's Misesian insight, their proposal is liable to result in a decline in economic stability, rather than an improvement.

\section{Limited Purpose Banking by Kotlikoff (2010)}

The Limited Purpose Banking proposal by Kotlikoff (2010) also falls into the $100 \%$ reserve central banking system because it pro- 
vides for $100 \%$ reserve requirements on checking accounts. The entire quantity of money is issued by the central bank. The proposal has an ambiguous effect on intertemporal discoordination and suffers from the same weakness as Benes and Kumhof (2013) by overlooking the fact that intertemporal discoordination also occurs when outside money is injected into the credit market.

On the one hand, the focus of Limited Purpose Banking is set on measures that mitigate intertemporal discoordination. Concretely, the purpose is to convert commercial banks into pure financial intermediaries such as mutual funds, contributing to align investment with voluntary savings. Moreover, mutual funds would be $100 \%$ funded by shareholders' equity, preventing runs from coming about. ${ }^{28}$ Clearly, the cornerstones of the proposal reduce intertemporal discoordination and improve economic stability.

On the other hand, however, the role of the central bank, though relegated to the background of the proposal, is at odds with the principle of converting banks into pure financial intermediaries. On page 174, Kotlikoff (2010) states:

[Monetary policy] will operate just as it does today. If the Fed wants to increase the money supply, it will print money and use it to buy assets from the private sector, typically the private sector's holdings of Treasuries. In the crisis, we've seen the Fed print money to buy other assets as well, indeed, even toxic assets. [...] Under Limited Purpose Banking, the Fed, if it wanted, could purchase and sell shares of the various mutual funds. Thus, if the Fed wished to quickly lower mortgage interest rates, it could do so by buying shares of mutual funds investing in mortgages.

When the additional quantity of outside money enters the credit market, a discrepancy between investment and voluntary savings arises even if the central bank cannot default. Since the entire quantity of money is created by the central bank, intertemporal discoordination will increase with money supply. Therefore, the reservations about the ability of the plan of Benes and Kumhof

28 This proposal corresponds to Simons (1936) ideal system (p. 6): «The danger of pervasive, synchronous, cumulative maladjustments would be minimized [...] if all property were held in a residual-equity or common stock form.» 
(2013) to bring about the desired stability equally apply to the proposal of Kotlikoff (2010).

\section{$\mathrm{V}$ CONCLUSION}

The process by which money is injected into the economy has far-reaching implications that go well beyond its influence on the price level. Whereas Cantillon (1755) shows that an increase in money affects economic agents unevenly, Mises (1912) emphasizes that a monetary injection into the credit market exacerbates intertemporal discoordination.

The monetary system defines the set of rules regulating the institutions which create money, and, thereby shapes the economic outcome of a monetary expansion. The system determines (i) the impact of an expansion of money on the Cantillon and Mises effects, (ii) the limit to expansion, and (iii) the extent to which the discrepancy between investment and voluntary savings which arises with intertemporal discoordination is resolved by inflation, default, or investment liquidation. Thus, the monetary system shapes the length and severity of boom-bust cycles.

The choice of monetary system must support the pursuit of the policy objective. Two conclusions can be drawn from our analysis. First, the pursuit of price level stability in the fractional reserve central banking system entails unintended consequences because the increase in money necessary to stabilize the price level gives rise to a credit expansion, which exacerbates intertemporal discoordination. This dilemma calls for either changing the objective and tolerating sound deflation, or changing the monetary system such that an increase in money does not exacerbate intertemporal discoordination.

Second, although the proposal of Benes and Kumhof (2013) to adopt a $100 \%$ reserve central banking system is reminiscent of the 100\%-Money plan by Fisher (1936), it actually pursues a different policy objective. Whereas Fisher promotes the 100\%-Money plan on the grounds that it reduces intertemporal discoordination, Benes and Kumhof (2013) promote their Chicago Plan Revisited on 
the opposite grounds that the central bank can better engage in credit expansion by lowering interest rates below zero more effectively than under the fractional reserve central banking system, which exacerbates intertemporal discoordination. Whereas the Limited Purpose Banking proposal of Kotlikoff (2010) aims at converting commercial banks into pure financial intermediaries, which mitigates intertemporal discoordination, it provides for the injection of outside money by the central bank into the credit market, which exacerbates intertemporal discoordination. Though all these proposals can be subsumed under the heading of the $100 \%$ reserve central banking system, their precise design means that they actually deliver very different economic outcomes.

\section{BIBLIOGRAPHICAL REFERENCES}

Admati, A. And Hellwig, M. (2013): The Bankers' New Clothes: What's Wrong with Banking and What to Do About It. Princeton University Press, Princeton.

Angell, J. W. (1935): The 100 per cent reserve plan. The Quarterly Journal of Economics, 50(1):1-35.

AtKeson, A. and Kehoe, P. J. (2004): Deflation and depression: Is there an empirical link? Federal Reserve Bank of Minneapolis Staff Report, (331).

Bagus, P. (2010): Austrian business cycle theory: Are 100 percent reserves sufficient to prevent a business cycle? Libertarian $\mathrm{Pa}$ pers, 2(2):1-18.

- (2014): Austrian economics and new currency theory on $100 \%$ banking: A response to Huber. Procesos de Mercado: Revista Europea de Economia Politica, 11(1):105-136.

BAGUS, P. and Howden, D. (2010a): Fractional reserve free banking: Some quibbles. The Quarterly Journal of Austrian Economics, 13(4):29-55.

- (2010b): The term structure of savings, the yield curve, and maturity mismatching. The Quarterly Journal of Austrian Economics, 13(3):64-85.

Benes, J. and KumHof, M. (2013): The Chicago Plan Revisited. IMF mimeo. 
Bernholz, P. (1993): The importance of Böhm-Bawerk's theory of capital and interest from an historical perspective. History of Economic Ideas, 1(2):21-58.

BÖHM-BAWERK, E. v. (1889): Capital and Interest: Positive Theory of Capital. [Reprint by Libertarian Press, Pennsylvania, 1959], Vienna. Bordo, M., LANE, J. L., and ReDish, A. (2004): Good versus bad deflation: lessons from the gold standard era. NBER Working Paper Series, (10329).

Cantillon, R. (1755): Essai sur la nature du commerce en général. Fletcher Gyles, London.

FisHeR, I. (1936): «100\% Money». Adelphi Company, New York.

Friedman, M. and Schwartz, A. (1963): A Monetary History of the United States, 1867-1960. Princeton University Press, Princeton.

Fullarton, J. (1844): On the regulation of currencies. John Murray, London.

GARRISON, R. W. (2004): Overconsumption and forced saving in the Mises-Hayek theory of the business cycle. History of Political Economy, 36(2):323-349.

HayeK, F. A. (1935): Prices and Production. Augustus M. Kelly, New York.

- (1928): Intertemporal price equilibrium and movements in the value of money. Weltwirtschaftliches Archiv, 28:33-76. [Reprint by Liberty Fund, Good Money, Part I, ed. Stephen Kresge, 1999].

Huber, J. (2011): Monetäre Modernisierung. Metropolis-Verlag, Marburg.

HuerTa De Soto, J. (2009): Money, Bank Credit, and Economic Cycles. 2nd Edition, Ludwig von Mises Institute, Auburn, Alabama, US. KIRZNER, I. M. (1993): The pure time-preference theory of interest: An attempt at clarification. In Herbener, J. M., editor, The Meaning of Ludwig von Mises: Contributions in Economics, Sociology, Epistemology, and Political Philosophy. Ludwig von Mises Institute, Auburn, Alabama, US.

KотLIKOFF, L. J. (2010): Jimmy Stewart is Dead: Ending the World's Ongoing Financial Plague with Limited Purpose Banking. Wiley, Hoboken, New Jersey.

LUCAS, R. E. J. (1972): Expectations and the neutrality of money. Journal of Economic Theory, 4:103-124. 
McLeay, M., Radia, A., and Thomas, R. (2014): Money creation in the modern economy. Bank of England Quarterly Bulletin.

Menger, C. (1871): Principles of Economics. [Reprint by New York Universtiy Press,New York, 1976], Vienna.

Mises, L. v. (1912): The Theory of Money and Credit. [Reprint by Liberty Fund, Indianapolis, 1981], Vienna.

- (1949): Human Action. [Reprint by the Ludwig von Mises Institute, Auburn, Alabama, 1998].

Phillips, C. A., McManus, T. F., and Nelson, R. W. (1937): Banking and Business Cycle. Arno Press, New York.

Rothbard, M. (1962): Man, Economy, and State. [Reprint by the Ludwig von Mises Institute, Auburn, Alabama, US, 2009].

- (1963): America's Great Depression. [Reprint by the Ludwig von Mises Institute, Auburn, Alabama, US, 2013].

Selgin, G. (1994): Free banking and monetary control. The Economic Journal, 104(427):1449-1459.

SimONS, H. C. (1936): Rules versus authorities in monetary policy. Journal of Political Economy, 44(1):1-30.

WiCKSELL, K. (1898): Interest and Prices. Macmillan, trans. Richard Kahn (1936), London. 